\title{
CSF Rhinorrhoea with Encephalocele through Sternberg's Canal: Our Experience
}

\author{
Reshma Hanwate, Vandana Thorawade, Mohan Jagade, Anoop Attakil, Kartik Parelkar, \\ Madhavi Pandare, R. V. Natraj, Rajesh Kar \\ Department of ENT, Grant Government Medical College \& Sir J J Hospital, Mumbai, India \\ Email: drreshma06@gmail.com
}

Received 19 December 2014; accepted 19 January 2015; published 26 January 2015

Copyright @ 2015 by authors and Scientific Research Publishing Inc.

This work is licensed under the Creative Commons Attribution International License (CC BY). http://creativecommons.org/licenses/by/4.0/

c) (7) Open Access

\begin{abstract}
Spontaneous cerebrospinal fluid rhinorrhoea with encephalocele restricted to the sphenoid sinus is rare clinical finding. As of today, only 17 cases encephalocele protruding through the Sternberg's canal and extending into the lateral recess of sphenoid sinus, have been described in literature. Patients presenting with this special clinical entity usually do not have any history of trauma, tumour or iatrogenic injury. Thus the lesions are considered to originate from a congenital bony defect in the lateral wall of the sphenoid sinus, first described by Sternberg in 1888 as the lateral craniopharyngeal canal (Sternberg's canal). In our experience each patient of spontaneous CSF rhinorrhea should have suspicion of intrasphenoid encephalocele though cribriform plate is a common site. Endoscopic tranasnasal approach is one of the best modalities for such cases.
\end{abstract}

\section{Keywords}

CSF Rhinorrhoea, Sternberg's Canal, Encephalocele

\section{Introduction}

Spontaneous cerebrospinal fluid leaks with encephaloceles restricted to the sphenoid sinus are rare. As of today, only 17 cases protruding through the Sternberg's canal and extending into the laterals recess of sphenoid sinus, have been described in literature [1]-[3]. Associations among persisting Sternberg's canal, extensively pneumatised sphenoid sinuses, elevated intracranial pressure and obesity are discussed as possible reason for spontaneous CSF rhinorrhoea and encephaloceles in this region. Spontaneous sphenoidal encephaloceles are uncommon entities and the presence of lateral sphenoidal encephalocele is a rare congenital anomaly [4]. Cranial encephaloceles, herniation of intracranial meninges and brain tissue through a defect in the cranium or skull base, are rare conditions with an incidence of approximately 1 in 35,000 people, and are more common in the anterior cranial 
fossa than those in the middle one [3]-[7]. Basal encephaloceles represent up to $10 \%$ of them [7]. Intrasphenoidal encephaloceles are extremely rare findings. Temporal lobe herniation through a middle fossa defect into the lateral recess of the SS is even rarer than the medial localization, and it is probably the least common type of basal encephaloceles [6] [8]-[10].

\section{Case Report}

A 39-year-old, multiparous, obese female presented to our out patient departement with complain of spontaneous watery nasal discharge through nose associated with refractory headache since 9 months. $\beta 2$ transferrin test was found to be positive. HRCT PNS (high resolution computed tomography of paranasal sinuses) (Figure 1) revealed the bony defect in the lateral wall of sphenoid sinus with soft tissue protruding through it, MRI (magnetic resonanace imaging) (Figure 2) showed herniation of brain tissue through the same with empty sella.

Following pre-aneasthetic fitness endoscopic examination of nasal cavity was done. Patient was posted for the repair of the defect by an endoscopic transnasal approach. Herniated brain tissue (Figure 3) was cauterised with angled bipolar cautery and removed. The defect was closed in TRIPLE LAYER fashion which consisted of fat tissue, tensor fascia lata and biological glue. The first layer i.e. fat tissue was by kept by Wormold bath plug technique. The triple layer technique offers the advantage of reconstituting the layers of the skull base and thus may reduce the long-term failure rates. The post operative period was uneventful. No recurrence was found after 6 months of interval.

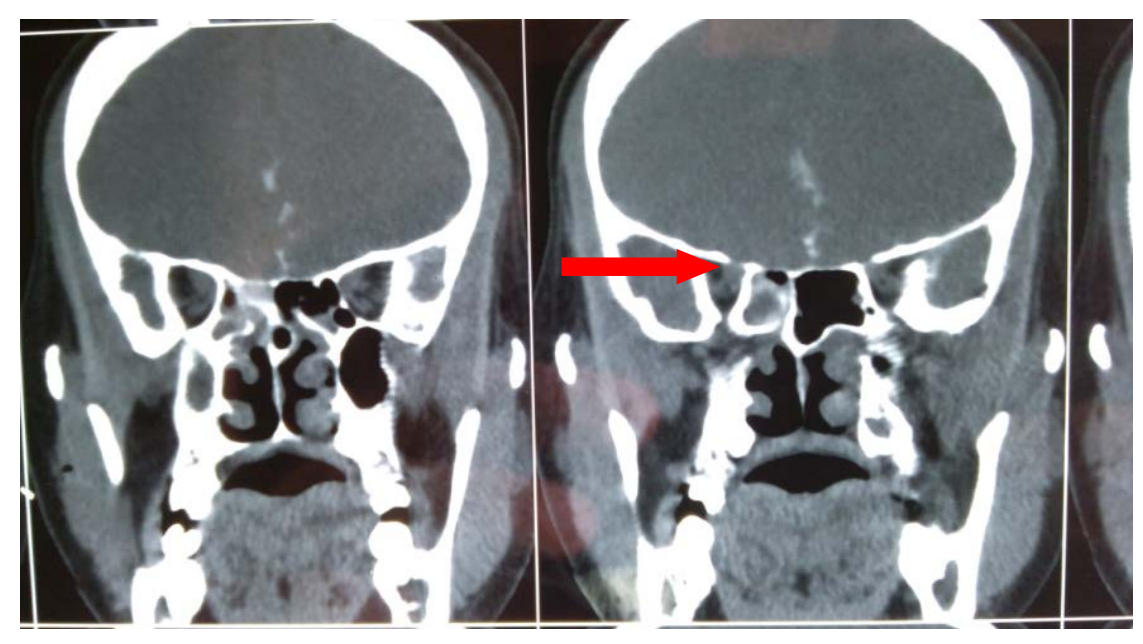

Figure 1. CT showing site of leak in sphenoid sinus.

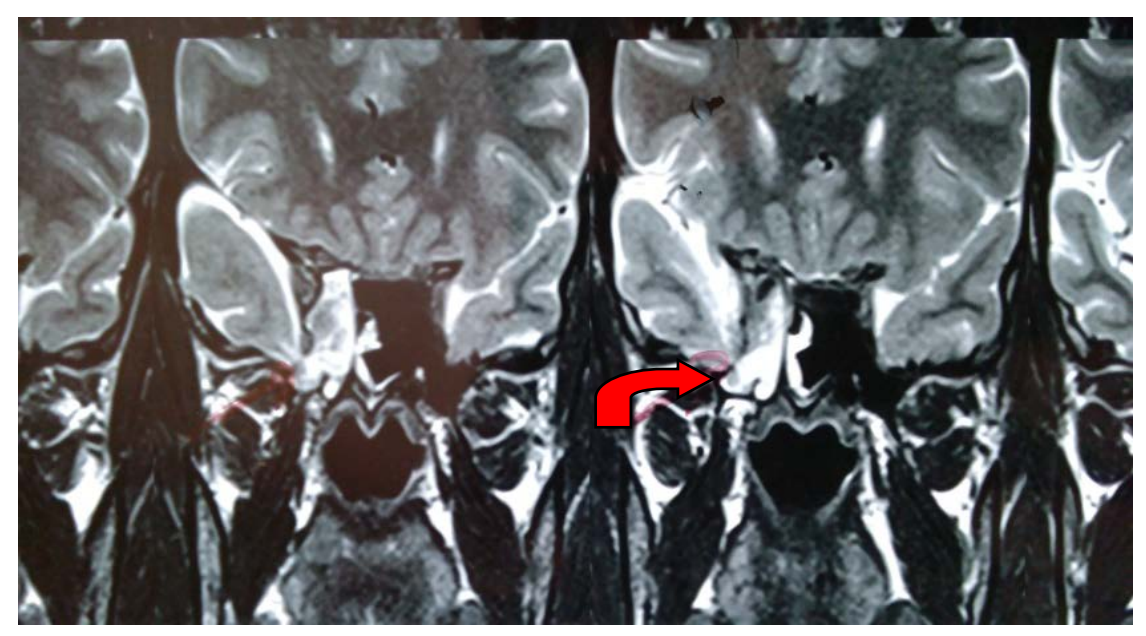

Figure 2. Encephalocele through defect. 


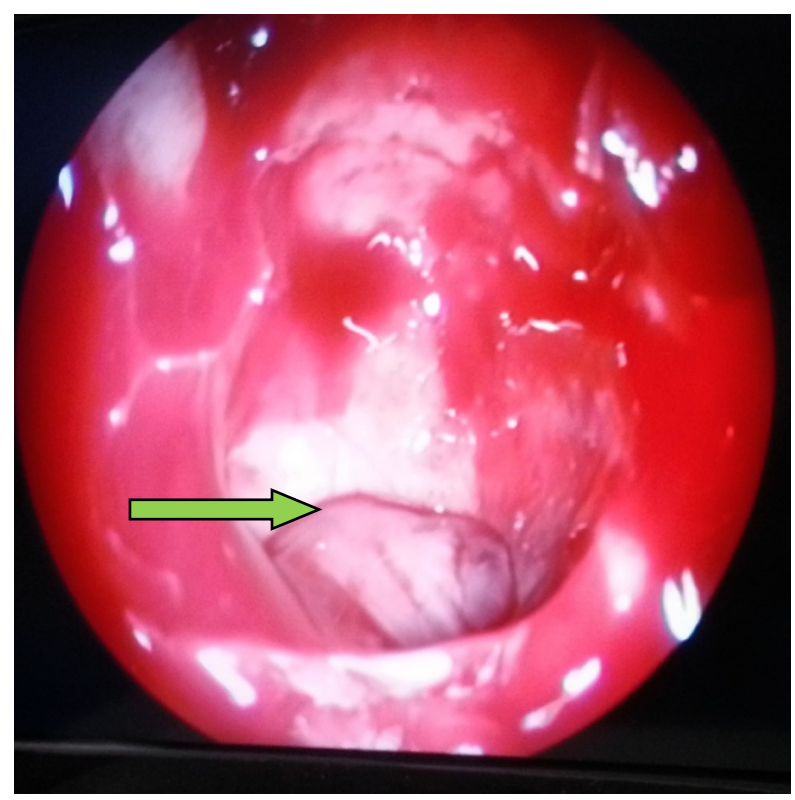

Figure 3. Endoscopic view of herniated brain tissue through defect.

\section{Discussion}

The sphenoid sinus (SS) is widely variable in its anatomy and degree of pneumatization. It reaches its full size during adolescence [7] [8] [11]. Anatomically it is extended laterally upto the line connecting the medial edges of the anterior opening of the vidian canal and the extracranial end of the foramen rotundum [7]. The lateral recess of the SS is an extensive lateral pneumatization of the SS into the pterygoid process, the great wing of the sphenoid bone or both, and it is also known as lateral type of sinus [7] [8] [11]-[13]. Rarely, it may extend up to the foramen ovale [14]. Lewin et al. found that 41 of 72 patients had lateral recess formation on at least one side and Barañano et al. found it in 35.3\% of 1000 CT scans [8].

The sphenoid bone has several independent cartilaginous ossifiction centres, presphenoid and postsphenoid/ basisphenoid centers (body of the sphenoid bone), orbitosphenoids (lesser wings), and alisphenoids (greater wings). Union of these ossified components results in formation of the sphenoid bone [15] [16]. If the posterior portion of the bony fusion of the greater wings with the bone's body is incomplete, it creates a lateral craniopharyngeal canal, which was described by Sternberg in 1888. In the presence of a lateral recess of the SS, the Sternberg's canal can communicate with the SS after its pneumatization, acting as a possible site of origin of congenital encephaloceles. As the resistance to pneumatization at fusion plane is more, so sphenoidal defects at these planes are more likely to be congenital than acquired [10] [16]-[19]. Sternberg's canal has been reported in up to $4 \%$ of adults, but Barañano et al. found only one case in 1000 CT scan. Obesity may be the cause of CSF leak, increased weight increases intraabdominal and intrathoracic pressure which could lead to the development of benign intracranial hypertension [13] [17]. CSF rhinorrhea is the most common clinical manifestation of temporal encephaloceles through Sternberg's canal and other previously occult malformations of the skull base. The CSF drainage is generally intermittent and not voluminous and may be ignored by the patient for a long time until complicated by meningitis. Recurrent meningitis may also occur. Others signs and symptoms of this entity are chronic headache, seizures and vertigo.

Patients with encephaloceles within the lateral recess of the SS classically present with CSF rhinorrhea during adulthood, enhancing the importance of pneumatization of the SS in the pathogenesis [19]. Regarding neuroradiological investigations, CT scan is a noninvasive imaging technique which gives good bone detail and identifies the site of the skull base defect. CT cisternography consists of injecting intrathecal water-soluble contrast medium before the CT scan and then visualizing it at the level of the dural and skull base defect. Intermittent or inactive CSF leaks are usually associated with a high incidence of false-negative results and MR imaging may be a better choice in those patients [1] [10] [14] [19]. MR images are more informative for soft tissues like the 
encephalocele itself [2]. If radiological images may also show partial or complete opacity of the SS [3]. Then, the site of leak is confirmed at the time of surgery [9].

Persistent CSF leak is potentially lethal because it may lead to meningitis or brain abscess. Thus, repair of intrasphenoidal encephaloceles has two main objectives: prevention of CSF leak and to avoid central nervous system infection [2] [6] [13] [18].

Surgical treatment should be tailored to each patient. Endoscopic transnasal approaches are less invasive and do not require a large external incision and temporal lobe retraction, minimizing brain manipulation [2] [5] [9] [13] [17]-[20].

\section{Conclusions}

A persisting Sternberg's canal should be considered the source of spontaneous CSF leak with or without encephalocele in sphenoid sinuse with extensive lateral pneumatisation. Endoscopic repair of such leaks is very technically challenging. Nevertheless, endoscopic transnasal surgery is safe as no intraoperative complications occur in our patient. It is less traumatic than transcranial approaches providing a good access and view of the surgical field.

Endoscopic management of CSF leaks represents an early but elegant example of the evolution and effectiveness of transnasal endoscopic techniques in managing various sinonasal and skull base pathology.

\section{References}

[1] Buchfelder, M., Fahlbusch, I., Huk, W.J. and Thierauf, P. (1987) Intrasphenoidal Encephalocele-A Clinical Entity. Acta Neurochirurgica, 89, 10-15. http://dx.doi.org/10.1007/BF01406661

[2] Blaivie, C., Lequeux, T., Kampouridis, S., Louryan, S. and Saussez, S. (2006) Congenital Transsphenoidal Meningocele: Case Report and Review of the Literature. American Journal of Otolaryngology, 27, 422-444. http://dx.doi.org/10.1016/j.amjoto.2006.01.011

[3] Schick, B., Brors, D. and Prescher, A. (2000) Sternberg's Canal-Cause of Congenital Sphenoidal Meningocele. European Archives of Oto-Rhino-Laryngology, 257, 430-432. http://dx.doi.org/10.1007/s004050000235

[4] Buchfelder, M., Fahlbusch, R., Huk, W.J. and Thierauf, P. (1987) Intrasphenoidal Encephaloceles-A Clinical Entity. Acta Neurochirurgica, 89, 10-15. http://dx.doi.org/10.1007/BF01406661

[5] Kwon, J.E. and Kim, E. (2010) Middle Fossa Approach to a Temporosphenoidal Encephalocele. Technical Note. Neurologia Medico-Chirurgica, 50, 434-438. http://dx.doi.org/10.2176/nmc.50.434

[6] Lopatin, A.S., Kapitanov, D.N. and Potapov, A.A. (2003) Endonasal Endoscopic Repair of Spontaneous Cerebrospinal Fluid Leaks. Archives of Otolaryngology—Head and Neck Surgery, 129, 859-863. http://dx.doi.org/10.1001/archotol.129.8.859

[7] Wang, J., Bidari, S., Inoue, K., Yang, H. and Rhoton Jr., A. (2010) Extensions of the Sphenoid Sinus: A New Classification. Neurosurgery, 66, 797-816. http://dx.doi.org/10.1227/01.NEU.0000367619.24800.B1

[8] Lewin, J.S., Curtin, H.D., Eelkema, E. and Obuchowski, N. (1999) Benign Expansile Lesions of the Sphenoid Sinus: Differentiation from Normal Asymmetry of the Lateral Recesses. American Journal of Neuroradiology, 20, 461-466.

[9] Tabaee, A., Anand, V.K., Cappabianca, P., Stamm, A., Esposito, F. and Schwartz, T.H. (2010) Endoscopic Management of Spontaneous Meningoencephalocele of the Lateral Sphenoid Sinus. Journal of Neurosurgery, 112, 1070-1077. http://dx.doi.org/10.3171/2009.7.JNS0842

[10] Schlosser, R.J. and Bolger, W.E. (2003) Significance of Empty Sella in Cerebrospinal Fluid Leaks. OtolaryngologyHead and Neck Surgery, 128, 32-38. http://dx.doi.org/10.1067/mhn.2003.43

[11] Rhoton Jr., A.L. (2002) The Sellar Region. Neurosurgery, 51, S335-S374. http://dx.doi.org/10.1097/00006123-200210001-00009

[12] Ciobanu, I.C., Motoc, A., Jianu, A.M., Cergan, R., Banu, M.A. and Rusu, M.C. (2009) The Maxillary Recess of the Sphenoid Sinus. Romanian Journal of Morphology and Embryology, 50, 487-489.

[13] Lai, S.Y., Kennedy, D.W. and Bolger, W.E. (2002) Sphenoid Encephaloceles: Disease Management and Identification of Lesions within the Lateral Recess of the Sphenoid Sinus. The Laryngoscope, 112, 1800-1805. http://dx.doi.org/10.1097/00005537-200210000-00018

[14] Devi, B.I., Panigrahi, M.K., Shenoy, S., Vajramani, G., Das, B.S. and Jayakumar, P.N. (1999) CSF Rhinorrhoea from Unusual Site: Report of Two Cases. Neurology India, 47, 152-154.

[15] Nemzek, W.R., Brodie, H.A., Hecht, S.T., Chong, B.W., Babcook, C.J. and Seibert, J.A. (2000) MR, CT, and Plain 
Film Imaging of the Developing Skull Base in Fetal Specimens. AJNR American Journal of Neuroradiology, 21, 16991706.

[16] Schick, B., Brors, D. and Prescher, A. (2000) Sternberg's Canal—Cause of Congenital Sphenoidal Meningocele. European Archives of Oto-Rhino-Laryngology, 257, 430-432. http://dx.doi.org/10.1007/s004050000235

[17] Castelnuovo, P., Dallan, I., Pistochini, A., Battaglia, P., Locatelli, D. and Bignami, M. (2007) Endonasal Endoscopic Repair of Sternberg's Canal Cerebrospinal Fluid Leaks. Laryngoscope, 117, 345-349. http://dx.doi.org/10.1097/01.mlg.0000251452.90657.3a

[18] Arai, A., Mizukawa, K., Nishihara, M., Fujita, A., Hosoda, K. and Kohmura, E. (2010) Spontaneous Cerebrospinal Fluid Rhinorrhea Associated with a Far Lateral Temporal Encephalocele-Case Report. Neurologia Medico-Chirurgica, 50, 243-245.

[19] Wind, J.J., Caputy, A.J. and Roberti, F. (2008) Spontaneous Encephaloceles of the Temporal Lobe. Neurosurgical Focus, 25, E11. http://dx.doi.org/10.3171/FOC.2008.25.12.E11

[20] Ohkawa, T., Nakao, N., Uematsu, Y. and Itakura, T. (2010) Temporal Lobe Encephalocele in the Lateral Recess of the Sphenoid Sinus Presenting with Intraventricular Tension Pneumocephalus. Skull Base, 20, 481-486. http://dx.doi.org/10.1055/s-0030-1261261 
Scientific Research Publishing (SCIRP) is one of the largest Open Access journal publishers. It is currently publishing more than 200 open access, online, peer-reviewed journals covering a wide range of academic disciplines. SCIRP serves the worldwide academic communities and contributes to the progress and application of science with its publication.

Other selected journals from SCIRP are listed as below. Submit your manuscript to us via either submit@scirp.org or Online Submission Portal.
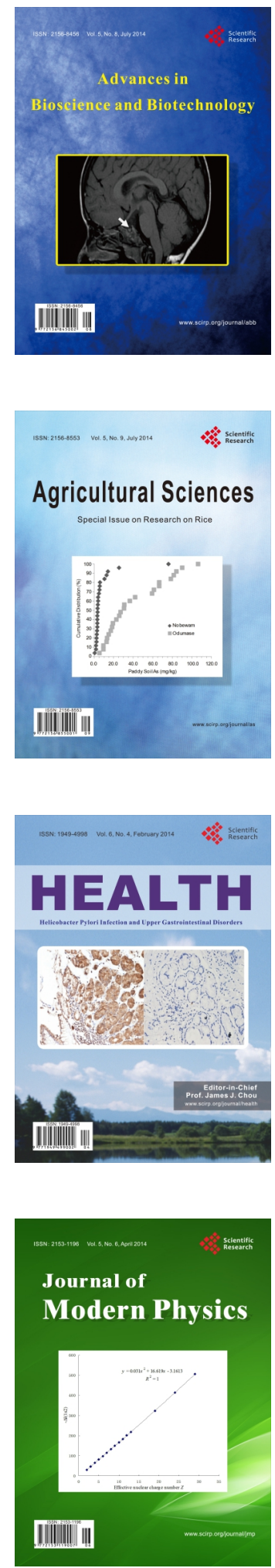
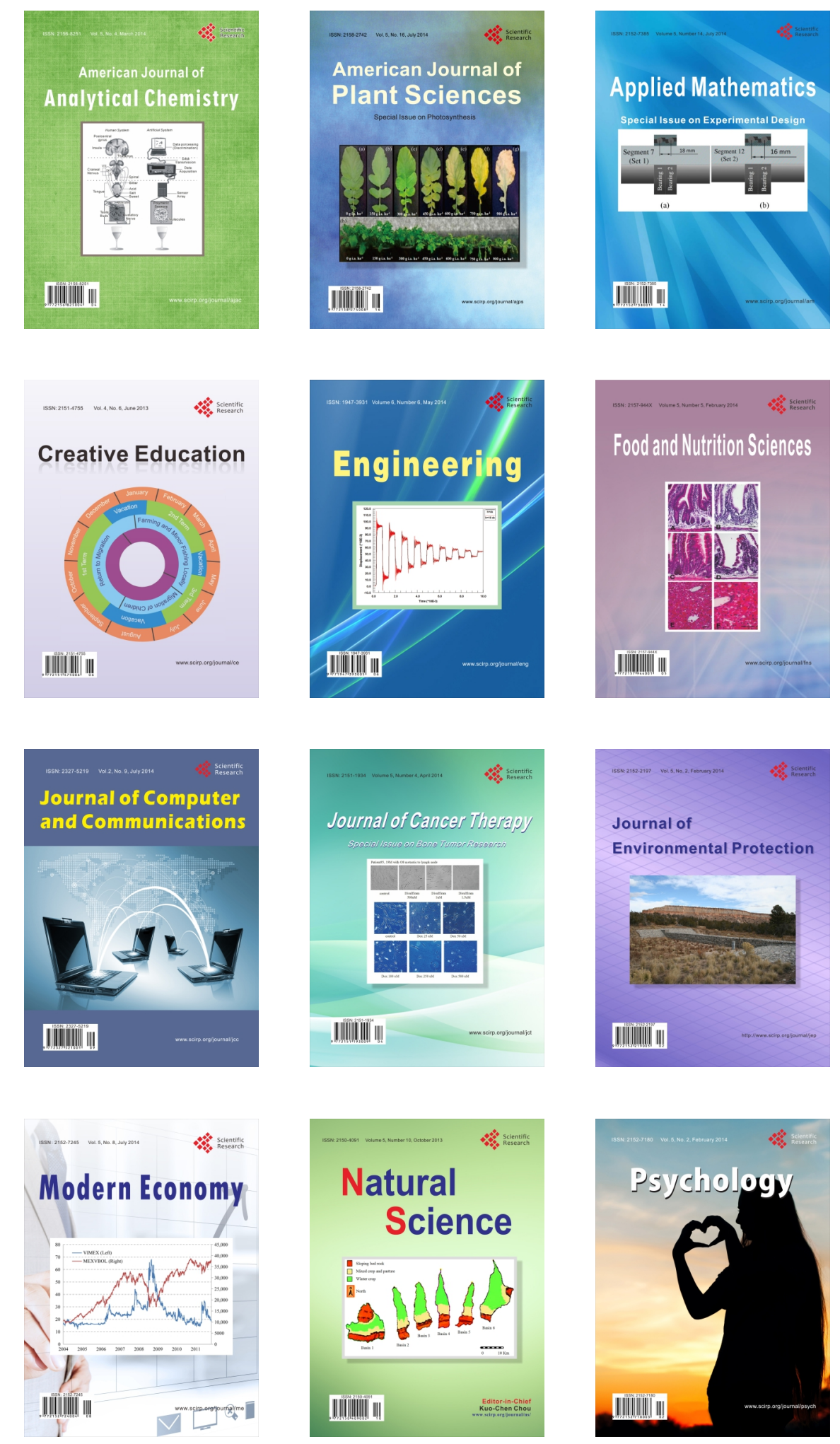